\title{
Correction: Selective and marked decrease of complement receptor C5aR2 in human thoracic aortic aneurysms: a dysregulation with potential inflammatory effects
}

Holt M, Seim BE, Øgaard J, et al. Selective and marked decrease of complement receptor C5aR2 in human thoracic aortic aneurysms: a dysregulation with potential inflammatory effects. Open Heart 2019;6:e001098. 10.1136/openhrt-2019-001098corr1.

First author's name was revised from 'Margrethe Holt' to 'Margrethe Flesvig Holt'.

Open access This is an open access article distributed in accordance with the Creative Commons Attribution Non Commercial (CC BY-NC 4.0) license, which permits others to distribute, remix, adapt, build upon this work non-commercially, and license their derivative works on different terms, provided the original work is properly cited, appropriate credit is given, any changes made indicated, and the use is non-commercial. See: http://creativecommons.org/licenses/by-nc/4.0/.

(C) Author(s) (or their employer(s)) 2020. Re-use permitted under CC BY-NC. No commercial re-use. See rights and permissions. Published by BMJ.

Open Heart 2020;7:e001098corr1. doi:10.1136/openhrt-2019-001098corr1

A) Check for updates 